\title{
IFRS VERSUS CZ GAAP: INFLUENCE OF CONSTRUCTION CONTRACTS ON FINANCIAL INDICATORS
}

\author{
Kristýna HAVLOVÁ ${ }^{1}$
}

\begin{abstract}
In 2009, 117 countries all over the world allowed to prepare financial statements according to International Financial Reporting Standards (IFRS) including the Czech Republic. Between Czech General Accepted Accounting Principles (CZ GAAP) and IFRS are some differences involving reporting of noncurrent fixed assets, leasing, construction contracts etc. Using different accounting procedure we can get different value of assets and assets are one component that is used to calculate the financial performance indicators. Those indicators are then used by investors to assess the financial performance of companies and the application of IFRS instead of CZ GAAP can lead to distinct presentation of enterprise performance. In this paper we examine the influence of construction contract reporting using IFRS and CZ GAAP on financial indicators. IFRS leads to more stable development during the period when the project is in progress. In the last year when the project is finished the figures of both ratios (ROA and Z-score) are getting worse which is due to the lower percentage of the construction that is built in this year.
\end{abstract}

\section{KEY WORDS}

construction contracts, IFRS, Czech accounting legislation, financial reporting, financial indicators

\section{JEL CLASSIFICATION}

F63, M14, M41

\section{INTRODUCTION}

International Accounting Standards Board (IASB) was established in 1972 in order to unify the accounting practices all around the world. The widest adoption started in 2002 when European Union (EU) directed the use of International Financial Reporting Standards (IFRS) for all companies that are listed on any of the European stock exchanges since 2005. Since 2000 International Financial Reporting Standards (IFRS) are allowed to be implemented into the national accounting legislations for all countries.

When the Czech Republic entered into the EU, one of the conditions was to implement the usage of IFRS for all consolidated financial statements and individual financial statements of listed companies while for tax purposes it is mandatory for all entities to report individual financial

\footnotetext{
${ }^{1}$ Correspondence address: Kristyna, Havlova, Ing.; +420 605298 658; xhavk27@ vse.cz; University of Economics in Prague, Department of Strategy, W. Churchill Square 4, 13067 Prague 3
} 
statements according to CZ GAAP. For the Czech enterprises this obligation means double reporting according to both CZ GAAP and IFRS.

In our research we want to show the influence of construction contracts on individual financial statements according to CZ GAAP and IFRS and the influence on financial indicators.

\section{REVIEW OF LITERATURE}

\subsection{Differences between accounting systems}

Each country has its own specifics and national regulation that expressively influence the amount and quality of disclosures. Some of the reasons are reporting traditions and discrepancies in national law requirements. (Barbu, Dumontier, \& Feleaga, 2014) Although the process of harmonization has begun in order to compare the financial statements across the countries, some countries prefer IFRS adoption more than the others. One of the reasons is economic network theory and based on this theory, the network effect is needed for IFRS adoption. This effect strength when the business partners come from the countries that use IFRS. (Ramanna \& Sletten, 2009) One of the most discussed advantages of the adoption are information costs. Those costs relate to knowledge of accounting standards by accountants, auditors, investors, financial analysts etc. (Márquez-Ramos, 2011) It also makes the work of financial analysts easier and the predictions of the development in such countries are more precise than in case of different accounting systems. (Bae, Tan, \& Welker, 2008)

When EU directed the use of IFRS for all entities listed on the European stock exchange and for consolidation purposes, the European countries had to implement IFRS into their national accounting legislation. This means a lot of amendments to accounting law e.g. in case of the Czech Republic from 1 May 2004 when the Czech Republic entered into EU, 22 amendments were issued. (Act No. 563/1991 Coll., on accounting, as amended)

The Czech Republic is affected by tax requirements demanded by Tax Authority (Strouhal \& Deari, 2011) while IFRS is primarily dedicated to shareholders decision-making. (Sucher \& Jindřichovská, 2004) Due to this, the Czech enterprises that want to prepare financial statements under IFRS have to issue disclosure under both IFRS and CZ GAAP. Between CZ GAAP and IFRS are some differences such as substance over form principle that are used in IFRS while in CZ GAAP the form over substance principle is used, valuation of fixed assets, revenues recognition etc. In this research we compare differences between construction contracts under CZ GAAP and IAS 11 Construction Contracts.

According to IAS 11 the construction contract is defined as a contract specifically negotiated for the construction of an asset or a group of interrelated assets and shall be applied in accounting in the financial statements of contractors.

\subsection{Financial reporting, performance and indicators}

Financial reporting is an essential source for presenting the financial performance through financial statements. Financial statements should be audited in order to present true and fair view of the financial position so investors could use this information for investment decision-making and not be misled. Measurement of company's performance is important for variety of management decisions. Financial performance is not used only by shareholders but also by other stakeholders such as employees, suppliers, customers or banks for risk assessment and setting of an appropriate interest risk rate. (Pratt, 2010) 
Various financial indicators can measure financial performance. Pavláková Dočekalová, Kocmanová, \& Koleňák (2015) identified the financial indicators that reflected the company's sustainability according to top management. From 25 indicators the most important are Return on Assets (ROA) and cash flow. Jennings (2003) explains that Earnings before Interest and Taxes (EBIT) was composed because Earnings after Taxes (EAT) presented in financial statements did not reflect financial performance. EBIT is not influenced by taxes, financial or investment activities and therefore it is the appropriate indicator for operating operations assessment.

Focusing on long-term performance it is needed to connect the financial indicators with other company's components such as social responsibility or attitude to environment. Interconnecting all of the inputs (e.g. legal requirements, social comparison with competitors, technology investments, $\%$ woman in top management) the long-term financial performance is mainly reflected by Economic Value Added (EVA) and Return on Capital Employed (ROCE). (Epstein \& Roy, 2001) Studying 401 financial representatives (financial directors, shareholders, accountants etc.) it has been found that the most important indicator for external users is Earnings per Share (EPS) even more than cash flow. (Graham, Harvey, \& Rajgopal, 2005)

There were researched differences between IFRS and US GAAP and their influence on financial indicators. The variation was found in Return on Equity (ROE), inventories turnover and interest coverage ratio. On the other hand no differences were found in liquidity quick ratio. (Seay, 2014) Assessing the financial situation using bankruptcy model Z-score, 20\% of studied enterprises disclosed worse total result using IFRS than using CZ GAAP. $80 \%$ of the entities did not note the change in total result but there were negative movements between $2 \%$ and $35 \%$ within the same zone. The most significant differences between partial indicators were noted in total assets. (Kubíčková, 2011)

In our research we want to show the influence of construction contracts on individual financial statements according to CZ GAAP and IFRS and the influence on financial indicators.

\section{METHODOLOGY}

\subsection{Accounting for construction contracts}

In CZ GAAP, the contracted amount is booked as receivable in balance sheet (BS) as asset and total expected income is recognized in deferred income in BS as liability. Deferred income is decreased by the invoiced amount that is accounted as income from work in progress (WIP) in profit and loss account (P/L) and obtained cash lowers receivables. When the company pays for the construction in progress the paid amount is booked as WIP that is valued in costs in BS as asset. Expenses related to WIP that are invoiced to the customer are booked in P/L and lower WIP. (Act No. 563/1991 Coll., on accounting, as amended)

Table 1 CZ GAAP booking

\begin{tabular}{||c|c|c||}
\hline SITUATION & DEBIT & CREDIT \\
\hline Contract signed & Receivables & Deferred income \\
\hline $\begin{array}{c}\text { Paid costs for construction by the construction } \\
\text { company }\end{array}$ & WIP & Cash \\
\hline Expenses that are part of invoice to customer & Expenses related to WIP & WIP \\
\hline Invoiced amount to customer & Deferred income & Income from WIP \\
\hline Paid invoice by customer & Cash & Receivables \\
\hline
\end{tabular}


According to IAS 11 there are two ways of revenues and expenses recognition: the stage of completion method (SoC) that is used when the company can estimate the costs or zero-profit method in case that the company cannot estimate the costs. IFRS requests to book the construction contracts as work in progress that is the same as in CZ GAAP. In this paper we book work in progress according to SoC method because the company is able to set the expected costs reliably. The percentage of completion is calculated as share of actual costs divided by the expected costs for the whole construction (cost to cost method). Using the same percentage the income from work in progress is booked in $\mathrm{P} / \mathrm{L}$ and the double entry for this transaction is booked in the amount of actual costs as expenses for work in progress and the rest of the amount increases the work in progress account. The receivables are accounted in the same amount as the issued invoice. The issued invoice amount is booked on separate account. (IAS 11 Construction contracts)

\section{Table 2 IFRS booking}

\begin{tabular}{||c|c|c||}
\hline \hline $\begin{array}{c}\text { SITUATION } \\
\text { company }\end{array}$ & DEBIT & CREDIT \\
\hline $\begin{array}{c}\text { Paid costs for construction by the construction } \\
\text { Invoiced amount to customer }\end{array}$ & Receivables & $\begin{array}{c}\text { Amount billed to } \\
\text { customers }\end{array}$ \\
\hline Paid invoice by customer & Cash & Receivables \\
\hline Revenues recognition & WIP & Income from WIP \\
\hline Expenses that are part of invoice to customer & Expenses from WIP & Income from WIP \\
\hline
\end{tabular}

In Table 1 and Table 2, the double-entry booking for each accounting system is described. This practice is also used in our calculations that are included in the Appendices at the end of this paper.

\subsubsection{Financial indicators}

Based on the literature review above we identified the indicators that influence the shareholder's decision-making process. During our research we focus on two selected indicators and show how the diverse accounting system changes the values of them. From the ratios we chose ROA and Zscore calculated by course of Altman model. The equations are according to (Kislingerová, 2010) as follows.

$\mathrm{ROA}=\frac{\mathrm{EBIT}}{\text { Assets }}$

Z-score $=0.717 * \frac{\mathrm{WC}}{\mathrm{Assets}}+0.847 * \frac{\mathrm{EAT}}{\mathrm{A}}+3.107 * \frac{\text { EBIT }}{\mathrm{A}}+0.42 * \frac{\text { Share capital }}{\text { Liabilities }}+0.998 * \frac{\text { Revenues }}{\mathrm{A}}$

When Z-score is higher than 2.9 the company belongs to the prosperity area, when the result is between 1.2 and 2.9 the company belongs to grey area and when the resulting value is below 1.2 the company is endangered by the potential bankruptcy.

\subsection{Illustrative example}

In order to show the influence of construction contracts on individual financial statements after $\mathrm{CZ}$ GAAP and IFRS we suppose that the only influenced items are those related to construction contracts and the rest of the financial statements notices no change in figures. For our research we use illustrative example.

The construction company presents the following items in the financial statements: 
Table 3 Illustrative example: Financial statements

\begin{tabular}{||c|c|c|c||}
\hline \hline ASSETS & $\begin{array}{c}\text { AMOUNT } \\
\text { IN MEUR }\end{array}$ & EQUITY AND LIABILITIES & $\begin{array}{c}\text { AMOUNT } \\
\text { IN MEUR }\end{array}$ \\
\hline $\begin{array}{c}\text { Non-current fixed } \\
\text { assets }\end{array}$ & 62 & Share capital & 120 \\
\hline Receivables & 34 & Short-term payables & 93 \\
\hline Cash & 117 & & \\
\hline
\end{tabular}

The company concludes the contract for 170 million of EUR (MEUR) that is expected to be finished during following 4 years. The entity expects expenses amounting to MEUR 154. According to the contracts the customer pays for the issued invoices each month in arrears for the first two years and the rest of the payments is paid after completion.

In Year 1 we assume that the costs incurred amount MEUR 42 and there is no change in total expected costs. The company issued invoices amounting to MEUR 38.5 and the customer paid MEUR 35 until the period ends.

In Year 2 the costs incurred during the period are MEUR 49, which is higher than the expectation by MEUR 3. Issued invoices equal to MEUR 42.2 out of which MEUR 38.3 is paid before the end of the year so as the rest of invoices from the previous period.

In Year 3 the costs incurred are MEUR 43, which is below the original expectation. There are no issued invoices but the company obtain MEUR 5, the rest of the invoiced amount.

In Year 4 the costs incurred in the period reach to MEUR 27, which is higher than MEUR 21 that represents the expected costs. The entity issues the rest of the invoices and the whole amount is paid by the customer.

The aim of our research is to show what differences in financial statements are caused by construction contracts under IFRS instead of under CZ GAAP and how it influences the selected financial indicators.

\section{RESULTS AND DISCUSSION}

Under IFRS we calculate the revenues and costs pursuant the stage of completion instead of invoiced amount during the period which causes higher revenues owing to the fact that the invoices are issued once a month in arrears and therefore the revenues in CZ GAAP are booked in later periods. (Appendix 1) During Year 1, the costs incurred are booked in the same period which causes the negative profit according to CZ GAAP while IFRS profit is positive. The same situation is in Year 2. In Year 3, there is zero profit under CZ GAAP because there are no issued invoices. Therefore, there are no revenues so as no costs related to those invoices. After IFRS negative profit in Year 4 is caused by the revenues that are lower than in prior years. This is due to the stage of completion because until Year $386.45 \%$ of the construction was finished while it was built only $13.55 \%$ in Year 4.

Using CZ GAAP the total project price is booked as receivable which is then decreased by the repayment of invoiced amount. This causes very high receivables which have declining trend for the whole period except of Year 3. There are paid only invoices from previous periods. Work in 
progress exists in Year 3 because there are no issued invoices and no expenses related to WIP. In year 4, there is depression in receivables as the rest of them is paid.

Balance sheet pursuant IFRS shows more stable development with no significant year-to-year movement. This was caused by more even distribution of receivables that are represented by actually issued invoices and not by the contracted price. Comparing IFRS and CZ GAAP BS it can be seen that the total assets are getting closer. In the last year, assets are the same for both accounting systems and they only differ in profit and retained earnings. While IFRS shows negative profit in Year 4 and retained earnings, CZ GAAP presents positive and large profit but shows accumulated loss.

\section{Figure 1 ROA}

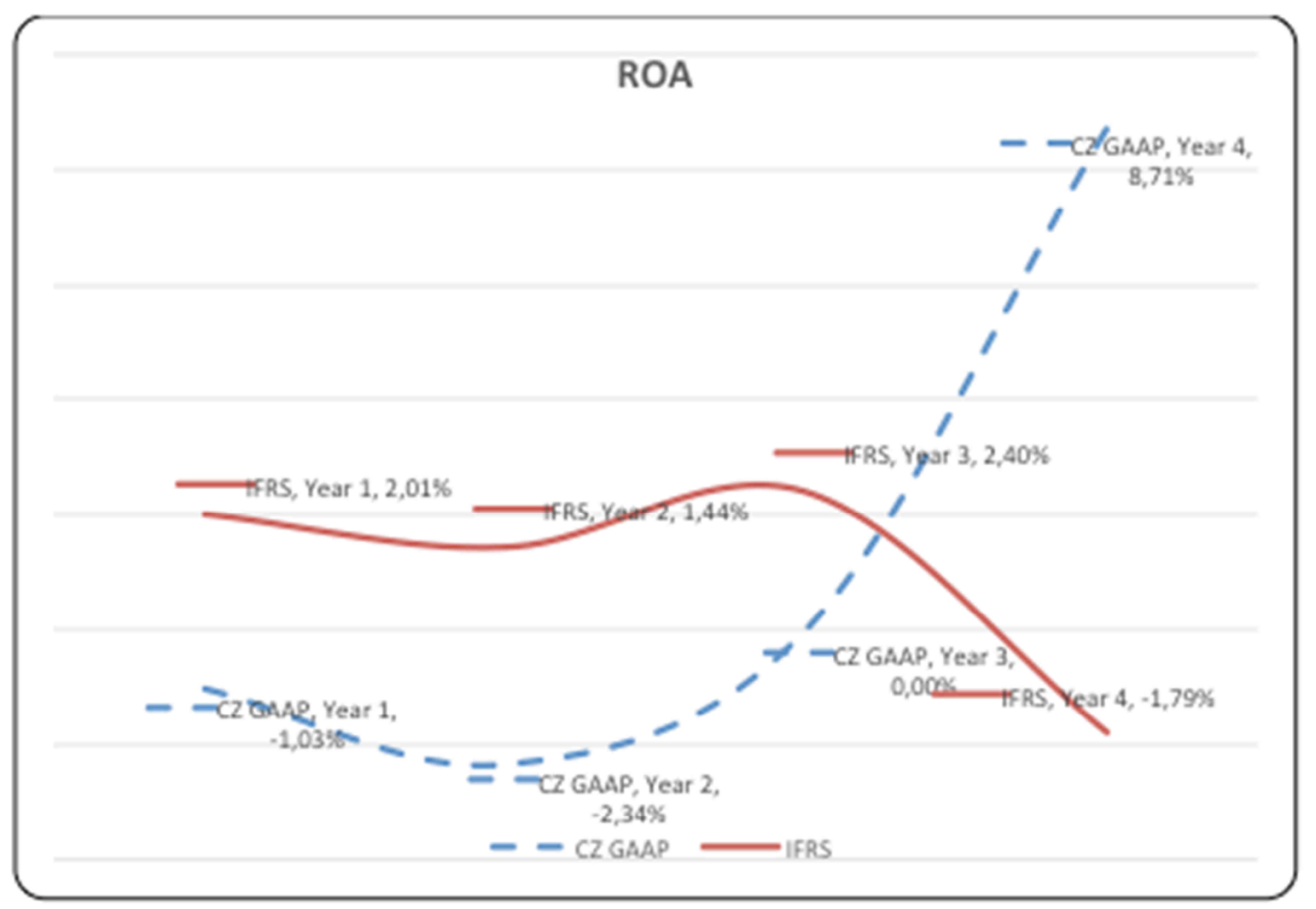

Return on assets should increase during the period in order to indicate the improving financial performance. As can be seen from Figure 1 IFRS shows stable values during Year 1, Year 2 and Year 3 while in Year 4 there is a significant fall and ROA is negative. This is connected with loss caused by low percentage of construction built in this year. On the contrary, CZ GAAP presents negative performance during the time when the project is in progress. In Year 4, there is a significant increase, which is represented by large profit with the same value of assets as in the case of IFRS. 
Figure 2 Z-score

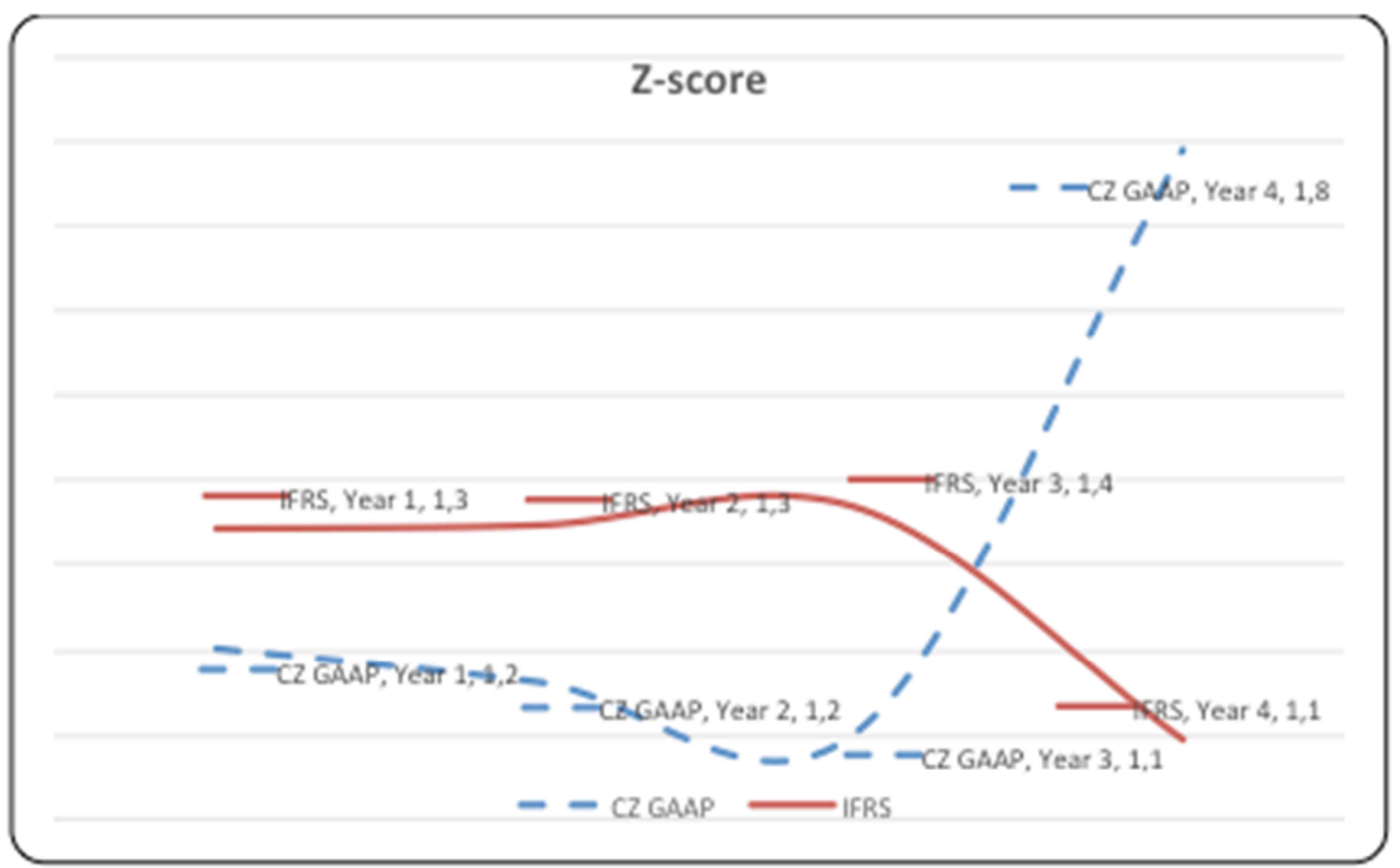

Z-score calculated according to CZ GAAP has in the first three years lower values than under IFRS. In Year 3, the company after CZ GAAP shows value 1.1 which is the area of potential bankruptcy. On the other hand, in Year 4 the value grows to 1.8 which represents grey zone and comparing with Year 3 the entity shows improving development. Pursuant IFRS there is a small increase between Year 1 and Year 3 when the figures are slightly above the line of potential bankruptcy. In Year 4, the development is opposite than in case of CZ GAAP when the numbers drop below this line and the company indicates potential bankruptcy risk.

There are two parts of Z-score that the most influence the values: WC/A and Rev/A. Rev/A has higher wage in the equation and the greater differences are noticeable. This is caused by the fact that IFRS shows more stable revenues during the period. In Year 4, the income declines. CZ GAAP on the contrary recognizes revenues with invoice issuing. In Year 4, the invoice for MCZK 89 is issued and therefore large revenues are recognized. Second factor are more stable assets according to IFRS while CZ GAAP presents greater asset balance. In Year 4, CZ GAAP shows the smallest assets with the highest revenues from all four years.

Assessing the company's performance using Z-score model, there is diverse interpretation of the results. After CZ GAAP we see that during the first three years the enterprise indicates problems with prosperity and there is a risk of potential bankruptcy. But when we check the figures in Year 4 we can state that the entity probably does some positive steps because Z-score raises significantly. According to IFRS the values show worse results because during the first four years the numbers are slightly above the bankruptcy line and in Year 4 the value drops down.

We have to emphasize that presenting worsening development by Z-score model can lead to the opinion that the company will actually have problems in the future and the shareholders could start to sell their shares in order to minimize the loss, which can end in the bankruptcy of the company. 


\section{CONCLUSION}

The different interpretation of financial indicators can lead to diverse investment decisions. It is necessary to emphasize that the financial indicators are based on the accounting data and therefore it is important to realize what exactly the differences in the accounting systems are.

In our research we assessed the influence of construction contracts under IFRS and CZ GAAP to the values of two performance indicators (ROA and Z-score model). Overall we can state that IFRS lead to more stable development during the period when the project is in progress. In the last year when the project is finished the figures of both ratios are getting worse which is due to the lower percentage of the construction that is built in this year. On the other hand, CZ GAAP presents fluctuation in the values with negative development but after the project completion both indicators show improved values than in case of IFRS. This is mostly owing to the assets that have increasing trend during the whole period and extremely large profit caused by the fact that invoices are issued in very significant amount. We also identified that booking construction contracts using different accounting system has very high influence on profit distribution between profit for current period and retained earnings. While IFRS shows raising retained earnings and loss for current period, CZ GAAP presents accumulated loss and high profit for current period.

Our finding of Z-score calculation showed the opposite result than (Kubíčková, 2011) during the period when the construction is in progress. On the other hand, we got the same results in the last year of construction when the development was worse after IFRS and the entity was transferred from grey area to the area of potential bankruptcy.

The limitation of the research is that we studied influence of only one project and assumed that there are no other differences between CZ GAAP and IFRS. For future research we are going to focus on the other items in the financial statements that can be variously interpreted using diverse accounting system. The partial researches should lead to assessing the overall influence of presenting the financial indicators under IFRS instead of CZ GAAP.

\section{Acknowledgements}

The forthcoming research is financed by the Internal Granting Agency of the University of Economics, Prague, project no. F3/34/2015.

\section{REFERENCES}

Act No. 563/1991 Coll., on accounting, as amended.

Bae, K.-H., Tan, H., \& Welker, M. (2008, May). International GAAP differences: The impact on foreign analysts. Accounting Review , 83(3), 593-628. doi:10.2308/accr.2008.83.3.593

Barbu, E. M., Dumontier, P., \& Feleaga, N. (2014, June). Mandatory environmental disclosures by companies complying with IASs/IFRSs: The cases of France, Germany, and the UK. International Journal of Accounting, 49(2), 231-247. doi:10.1016/j.intacc.2014.04.003

Epstein, M. J., \& Roy, M.-J. (2001). Sustainability in action: Identifying and measuring the key performance drivers. Long range planning , 34(5), 585-604. Retrieved from http://naulibrary.org/dglibrary/admin/book_directory/Bus_Admin/1673.pdf

Graham, J. R., Harvey, C. R., \& Rajgopal, S. (2005). The Economic Implications Of Corporate Financial Reporting. Journal of accounting and economics, 40(1), 3-73. Retrieved from http://core.ac.uk/download/pdf/6822971.pdf

IFRS Foundation. (n.d.). IAS 11 Construction contracts. 
Jennings, M. M. (2003). Ethics and Non-GAAP Financial Reporting. Internal Auditing, 18(6), 37 40 . Retrieved from http://media.proquest.com.zdroje.vse.cz/media/pq/classic/doc/499344171/fmt/pi/rep/NONE ?hl=us\%2Cus\%2Cgaap\%2Cgaap\%2Corigins\%2Corigin\%2Corigins\%2Corigin\&cit\%3Aaut $\mathrm{h}=$ Jennings $\% 2 \mathrm{C}+$ Marianne $+\mathrm{M} \& \mathrm{cit} \% 3 \mathrm{Atitle}=\mathrm{ETHICS}+\mathrm{AND}+\mathrm{NON}-$ GAAP+FINANCIAL+REPORTING\&cit\%3Apub=Internal+

Kislingerová, E. (2010). Manažerské finance (3 ed.). Praha: C. H. Beck.

Kubíčková, D. (2011). Účetní výkazy dle IFRS a bankrotní model Z-score. Journal of Competitiveness, 38-48. Retrieved from http://www.cjournal.cz/files/43.pdf

Márquez-Ramos, L. (2011, September 1.). European accounting harmonization: Consequences of IFRS adoption on trade in goods and foreign direct investments. Emerging Markets Finance and Trade , 47(SUPPL.4), 42-57. doi:10.2753/REE1540-496X4705S403

Pavláková Dočekalová, M., Kocmanová, A., \& Koleňák, J. (2015, March 30). Determination of economic indicators in the context of corporate sustainability performance. Business: Theory and Practice , 16(1), 15-24. doi:10.3846/btp.2015.450

Pratt, J. (2010). Financial Accounting in an Economic Context (8 ed.). USA: John Wiley \& Sons, Inc.

https://books.google.cz/books?id=F2J7ZS_EClMC\&pg=PA140\&dq=du+pont+financial+re porting \&hl=cs\&sa=X\&ved=0CB8Q6AEwAGoVChMI27SA0LHJxwIVic0UCh3KIwBl\#v= onepage $\& \mathrm{q}=\mathrm{du} \% 20$ pont $\% 20$ financial $\% 20$ reporting $\& \mathrm{f}=$ false

Ramanna, K., \& Sletten, E. (2009). Why do countries adopt International Financial Reporting Standards? Harvard Business School Accounting \& Management Unit Working Paper.

Seay, S. S. (2014). The economic impact of IFRS---a financial analysis perspective. Academy of Accounting and Financial Studies Journal, 2, pp. 119-140. Retrieved from http://search.proquest.com.zdroje.vse.cz/docview/1532759978/fulltextPDF/68D3207057B6 4C44PQ/1?accountid=17203

Strouhal, J., \& Deari, F. (2011). Measurement of accounting harmonization in the Czech Republic, Macedonia and Albania. 10th WSEAS International Conference on Instrumentation, Measurement, Circuits and Systems, IMCAS'11, (pp. 90-94). Venice. Retrieved from http://www.wseas.us/e-library/conferences/2011/Venice/IMCAS/IMCAS-15.pdf

Sucher, P., \& Jindřichovská, I. (2004). Implementing IFRS: A Case Study of the Czech Republic. 1(1), 109-141. Retrieved from http://www.adoptifrs.org/uploads/Czech/Implementing\%20IFRS\%20A\%20case\%20study\% 20of\%20the\%20Czech\%20Republic.pdf

\section{ATTACHEMENT 1}

\section{Profit}

\begin{tabular}{||c|c|c|c|c|c|c|c|c|c||}
\hline \hline & YEAR & YEAR & YEAR & YEAR & & YEAR & YEAR & YEAR & YEAR \\
IFRS & 1 & 2 & 3 & 4 & CZ GAAP & 1 & 2 & 3 & 4 \\
\hline Revenues & 46.4 & 52.2 & 48.4 & 23.0 & Revenues & 38.5 & 42.2 & 0.0 & 89.3 \\
\hline Costs & 42.0 & 49.0 & 43.0 & 27.0 & Costs & 42.0 & 49.0 & 0.0 & 70.0 \\
\hline Profit & 4.4 & 3.2 & 5.4 & -4.0 & Profit & -3.5 & -6.8 & 0.0 & 19.3 \\
\hline
\end{tabular}


ATTACHEMENT 2

\section{Balance sheet - CZ GAAP}

\begin{tabular}{||c|c|c|c|c|c|c|c|c|c||}
\hline ASSETS & $\begin{array}{c}\text { YEAR } \\
1\end{array}$ & $\begin{array}{c}\text { YEAR } \\
2\end{array}$ & $\begin{array}{c}\text { YEAR } \\
3\end{array}$ & $\begin{array}{c}\text { YEAR } \\
4\end{array}$ & CAPITAL & $\begin{array}{c}\text { YEAR } \\
1\end{array}$ & $\begin{array}{c}\text { YEAR } \\
2\end{array}$ & $\begin{array}{c}\text { YEAR } \\
3\end{array}$ & $\begin{array}{c}\text { YEAR } \\
4\end{array}$ \\
\hline $\begin{array}{c}\text { Long-term } \\
\text { assets }\end{array}$ & 62.0 & 62.0 & 62.0 & 62.0 & $\begin{array}{c}\text { Share } \\
\text { capital }\end{array}$ & 120.0 & 120.0 & 120.0 & 120.0 \\
\hline WIP & 0.0 & 0.0 & 43.0 & 0.0 & Profit & -3.5 & -6.8 & 0.0 & 19.3 \\
\hline Receivables & 169.0 & 130.7 & 125.7 & 34.0 & $\begin{array}{c}\text { Retained } \\
\text { earnings }\end{array}$ & 0.0 & -3.5 & -10.3 & -10.3 \\
\hline Cash & 110.0 & 99.3 & 61.3 & 126.0 & $\begin{array}{c}\text { Short-term } \\
\text { payables }\end{array}$ & 93.0 & 93.0 & 93.0 & 93.0 \\
\hline & & & & $\begin{array}{c}\text { Deferred } \\
\text { income }\end{array}$ & 131.5 & 89.3 & 89.3 & 0.0 \\
\hline Total assets & 341.0 & 292.0 & 292.0 & 222.0 & $\begin{array}{c}\text { Total } \\
\text { capital }\end{array}$ & 341.0 & 292.0 & 292.0 & 222.0 \\
\hline
\end{tabular}

\section{ATTACHEMENT 3}

\section{Stage of completion}

\begin{tabular}{||c|c|c|c|c||}
\hline & YEAR 1 & YEAR 2 & YEAR 3 & YEAR 4 \\
\hline Stage of completion & $27.27 \%$ & $57.96 \%$ & $86.45 \%$ & $100.00 \%$ \\
\hline Increase in stage of completion & - & $30.69 \%$ & $28.49 \%$ & $13.55 \%$ \\
\hline
\end{tabular}

\section{ATTACHEMENT 4}

\section{Balance sheet - IFRS}

\begin{tabular}{|c|c|c|c|c|c|c|c|c|c|}
\hline ASSETS & $\begin{array}{c}\text { YEAR } \\
1\end{array}$ & $\begin{array}{c}\text { YEAR } \\
2 \\
\end{array}$ & $\begin{array}{c}\text { YEAR } \\
3 \\
\end{array}$ & $\begin{array}{c}\text { YEAR } \\
4\end{array}$ & CAPITAL & $\begin{array}{c}\text { YEAR } \\
1\end{array}$ & $\begin{array}{c}\text { YEAR } \\
2 \\
\end{array}$ & $\begin{array}{c}\text { YEAR } \\
3 \\
\end{array}$ & $\begin{array}{c}\text { YEAR } \\
4\end{array}$ \\
\hline $\begin{array}{l}\text { Long-term } \\
\text { assets }\end{array}$ & 62.0 & 62.0 & 62.0 & 62.0 & $\begin{array}{l}\text { Share } \\
\text { capital }\end{array}$ & 120.0 & 120.0 & 120.0 & 120.0 \\
\hline $\begin{array}{l}\text { Due from } \\
\text { customers }\end{array}$ & 7.9 & 17.9 & 66.3 & 0.0 & Profit & 4.4 & 3.2 & 5.4 & -4.0 \\
\hline Receivables & 37.5 & 41.3 & 36.3 & 34.0 & $\begin{array}{l}\text { Retained } \\
\text { earnings }\end{array}$ & 0.0 & 4.4 & 7.5 & 13.0 \\
\hline Cash & 110.0 & 99.3 & 61.3 & 126.0 & $\begin{array}{c}\text { Short-term } \\
\text { payables }\end{array}$ & 93.0 & 93.0 & 93.0 & 93.0 \\
\hline Total assets & 217.4 & 220.5 & 226.0 & 222.0 & $\begin{array}{c}\text { Total } \\
\text { capital }\end{array}$ & 217.4 & 220.5 & 226.0 & 222.0 \\
\hline
\end{tabular}




\section{ATTACHEMENT 5}

\section{ROA calculation}

\begin{tabular}{||c|c|c|c|c|c||}
\hline & & YEAR 1 & YEAR 2 & YEAR 3 & YEAR 4 \\
\hline EBIT & CZ GAAP & -3.50 & -6.83 & 0.00 & 19.33 \\
\hline & IFRS & 4.36 & 3.17 & 5.43 & -3.97 \\
\hline Assets & CZ GAAP & 341 & 292 & 292 & 222 \\
\hline & IFRS & 217 & 221 & 226 & 222 \\
\hline
\end{tabular}

\section{ATTACHEMENT 6}

\section{Z-score calculation}

\begin{tabular}{||c|c|c|c|c|c||}
\hline & & YEAR 1 & YEAR 2 & YEAR 3 & YEAR 4 \\
\hline Working Capital (current assets) & CZ GAAP & 279 & 230 & 230 & 160 \\
\hline & IFRS & 155 & 159 & 164 & 160 \\
\hline Liabilities & CZ GAAP & 93 & 93 & 93 & 93 \\
\hline & IFRS & 93 & 93 & 93 & 93 \\
\hline Revenues & CZ GAAP & 39 & 42 & 0 & 89 \\
\hline WC/Assets & IFRS & 46 & 52 & 48 & 23 \\
\hline & CZ GAAP & 0.82 & 0.79 & 0.79 & 0.72 \\
\hline EAT/A & IFRS & 0.71 & 0.72 & 0.73 & 0.72 \\
\hline EBIT/A & CZ GAAP & -0.01 & -0.02 & 0.00 & 0.07 \\
\hline SC/L & IFRS & 0.02 & 0.01 & 0.02 & -0.01 \\
\hline & CZ GAAP & -0.01 & -0.02 & 0.00 & 0.09 \\
\hline REV/A & IFRS & 0.02 & 0.01 & 0.02 & -0.02 \\
\hline Z-score & CZ GAAP & 1.29 & 1.29 & 1.29 & 1.29 \\
\hline & IFRS & 1.29 & 1.29 & 1.29 & 1.29 \\
\hline & CZ GAAP & 0.11 & 0.14 & 0.00 & 0.40 \\
\hline & IFRS & 0.21 & 0.24 & 0.21 & 0.10 \\
\hline & CZ GAAP & 1.20 & 1.16 & 1.11 & 1.79 \\
\hline & IFRS & 1.34 & 1.35 & 1.37 & 1.09 \\
\hline
\end{tabular}

